\title{
Citizenship and Discontents: A Socio-Legal Analysis
}

\author{
Dr. Bhupinder Singh* and Dr. Vidyottma Jha**
}

\begin{abstract}
Citizenship is the utmost honored form of nationality and it has the wide as well as narrow connotation. According to Aristotle, "citizen is he "who has the power to take part in the deliberative or judicial administration of any state is said by us to be a citizen of that state." Therefore, it is primarily a relationship between an individual and the state and historically, the notion of citizenship initially arose in towns and city-states of Ancient-Greece and citizenship not given to women, slaves, or the poorer members of the community but for property owners. It was used by Romans as a method to distinguish the residents of the city of Rome from those peoples whose territories Rome had conquered and incorporated. Citizens have many rights and duties that are sometime denied or only partially extended to aliens and other non-citizens residing in a country. Citizenship thus includes within its purview a number of things like-right to vote; political rights, hold public offices, etc. The usual responsibilities of citizenship are taxation, allegiance and military service.

Thus if observation from the developments then it finds that maximum of the 20th century social movements which focus has been on the challenges of these entities stood to the state because only the state had the capacity and willingness to grant economic and social concessions. But there was a shift in the prevailing situation in the years 1960-1980 as the existing configuration between the state, civil society and the economy was increasingly challenged by market penetration which led to the augmentation of social movements which no longer target state institutions or do so it only in partial way. Their actions and interactions are frequently concerned with the everyday practices, re-shaping demands within specific organizational, legislative and political contexts. Therefore, such activism enlarges the understanding of the concept of citizenship so as to include demands relating to livelihood; division of resources; the production and dissemination of knowledge; and forms of civic participation and solidarity.
\end{abstract}

Keywords: Citizenship, Rights and Duties, Civic Participation, Legislative- Political Aspects, Globalization

\footnotetext{
*Associate Professor, School of Law, CHRIST (Deemed to be University) Delhi- NCR, India.

** Advocate, Supreme Court of India, New Delhi, India.
} 


\section{Citizenship and Discontents: A Socio-Legal Analysis}

\section{Introduction}

The people of any country depends upon the policies and governance of the government who is in power along with the effective role played by the opposition. The idea of citizenship was really very old and some countries in the world are there where they provide dual citizenship for the peoples belongs to that country. The citizenship come up with various rights and privileges as everyone wants to get and it also provide the protective shield as well. The notion of citizenship is the utmost honored form of nationality and it has the wide as well as narrow connotation. According to Aristotle, "citizen is he "who has the power to take part in the deliberative or judicial administration of any state is said by us to be a citizen of that state." Therefore, it is primarily a relationship between an individual and the state and historically, the notion of citizenship initially arose in towns and city-states of Ancient-Greece and citizenship not given to women, slaves, or the poorer members of the community but for property owners. It was used by Romans as a method to distinguish the residents of the city of Rome from those peoples whose territories Rome had conquered and incorporated. Citizens have many rights and duties that are sometime denied or only partially extended to aliens and other non-citizens residing in a country. Citizenship thus includes within its purview a number of things like-right to vote; political rights, hold public offices, etc. The usual responsibilities of citizenship are taxation, allegiance and military service.

So the main concept here that if observation from the developments then it finds that maximum of the 20th century social movements which focus has been on the challenges of these entities stood to the state because only the state had the capacity and willingness to grant economic and social concessions. But there was a shift in the prevailing situation in the years 1960-1980 as the existing configuration between the state, civil society and the economy was increasingly challenged by market penetration which led to the augmentation of social movements which no longer target state institutions or do so it only in partial way. Their actions and interactions are frequently concerned with the everyday practices, re-shaping demands within specific organizational, legislative and political contexts. Therefore, such activism enlarges the understanding of the concept of citizenship so as to include demands relating to livelihood; division of resources; the production and dissemination of knowledge; and forms of civic participation and solidarity. 


\section{Genealogy of Citizenship: Differentiating between Colonial Citizenship and Imperial Citizenship}

The concept of citizenship is an unclear so far and vital one and it is easy to take for granted yet almost impossible to engineer, depending as it does on diffusing ideas and imbuing attitudes. The purpose of the citizenship ideal in this situation is to articulate a sense of nationhood in a territory that has political unity but little else. From the pre-colonial situation come differences of peoples, language, culture, subsistence; from the colonial situation come differences due to educational and economic development, overlaying and distorting the pre-colonial disparities. It is for the independent governments to attempt to reconcile these differences. In contrast to the metropolitan power, they seek to inculcate citizenship in positive, formal ways. It is important, however, to distinguish concept/theory from reality/ practice; to differentiate statement from meaning and application, as interpretation, motive and intention are all-important. The question of the effectiveness of state intervention is raised, especially with reference to the level of democratic action possible where the majority of citizens are illiterate and remain within the traditional economy. The concept of citizenship is an idealized one. The concept varies between one society and another, and in the time and circumstance within each society. In the mind of the citizen the concept of citizen- ship is formed in a multitude of ways, frequently in an informal or casual manner. There is a gulf between the citizenship ideal and the reality that is accepted and understood in some societies but not in others. Usually the latter are those which are newly formed and whose need is to establish a national identity by affirming that such an identity exists. Older societies, which have grown together more naturally over the centuries, can afford to take the ideal of citizenship in their own society for granted whilst recognized its shortcomings in the everyday practice of its -members. But the gap between stated intention and reality is an important one to recognize in any conceptual framework. Citizenship may be taken as a form of cement, holding the society of a state together, becoming firmer with the passage of time. Whilst the concept will differ between one society and another, depending upon its aims and purpose as both conscious and unconscious, realised and unrealised, it is pertinent to ask in what way the government of a society can create or mould that concept (Small, 1977). ${ }^{1}$ 


\section{Grounds of Citizenship}

There are various legally recognized grounds for the citizenship where the people can claim for this and the norm that the nationality of children is the same as that of their parents, regardless of their place of birth also there. This concept of citizen opposite with "jus soli" as per this context the nationality is reliant on place of birth and in States in which the "jus sanguinis" principle applies like- i.e. France and Germany; a clash of jurisdiction may sometime arise when a child is born of parents who are citizens of another state as for instance, "a child born in the United States of French parents is an American citizen jure soli, but a French citizen jure sanguinis because his citizenship will depend upon the jurisdiction within which he happens to be in; in the United States he is a US citizen; in France, a Frenchman; in any other country he is both." The skirmishes consequential from the coinciding presence of these opposing claims of allegiance are generally settled between states when the state asserting its primary claim of allegiance has de facto jurisdiction of the individual in question by deferring jus sanguinis to jus soli. The notion of Jus soli is a latin term meaning law of the soil. Many countries follow jus soli, more commonly known as birthright citizenship and under this concept, citizenship of an individual is determined by the place where the individual was born. So a child of an immigrant is a citizen as long as he/she is born in the country of immigration.

The concept of "Jus sanguinis" is at what time a person obtains citizenship through descent as i.e., via their parents or ancestors independent of where he/ she is born as, a child born in India must have at least one parent who is an Indian citizen to be conferred citizenship. Before the amendment to the Citizenship Act, $1955^{2}$, the person born in India considered as citizen regardless of the citizenship held by parents.

Anyone born in India must have at least one Indian parent to get citizenship by birth after the commencement of the Citizenship (Amendment) Act, 2003 and as per this "a person who born outside India can obtain citizenship by descent through parents and a foreigner married to an Indian citizen can obtain Indian citizenship after being ordinarily resident in India for seven years before making the application." Although, legal residents also adore various rights analogous to citizens and the different types of rights such as the employment right, right to travel, education right and there are certain rights which are exclusive to citizens only like- right to buy property or to vote in 
the Indian scenario. One cannot change nationality but can change citizenship upon compliance with legal formalities of the country whose citizenship one seeks to acquire as a person is a national of the state he/ she is born in, can be a citizen of another state and be a resident of a third state. One can be a resident of a state and still not be a citizen, for example, an individual born in India, can be an American citizen holding a United States passport and a British resident permit because some countries allow dual citizenship, thereby allowing their citizens to acquire citizenship of another country (Ghosh, Sep 13, 2018). ${ }^{3}$

Citizenship is a clear concept where it come up with privileges and benefits along with fundamental rights and duties as per the Constitution of India. But the parallel concept is the those who are not cover under the concept of citizenship as they are considered as migrants and generally, a difference is made between time-being migration which cover movements with a duration between 3-12 months along with permanent migration, denoting to a transformation of country of residence for a duration of one year or more (UN, n.d). ${ }^{4}$ Refugees are among the most vulnerable people in the world. While there is no formal legal definition of an international migrant, most experts agree that an international migrant is someone who changes his or her country of usual residence, irrespective of the reason for migration or legal status. Refugees are persons who are outside their country of origin for reasons of feared persecution, conflict, generalized violence, or other circumstances that have seriously disturbed public order and, as a result, require international protection. ${ }^{5}$ The conditions belong to the Refugees are really pitiable in any country and convention and protocols are there for providing protection and well-being and it elucidate the rights of refugees and the obligations ${ }^{6}$ and universal accession to the Refugee Convention is a valid and achievable goal for the welfare and protection aspects (UNHCR September 2011). ${ }^{7}$ The migrants and refuges are come under the aspect of natural rights and human rights perspectives, therefore, internationally and nationally the efforts must be made for the protection and fulfilling basic rights.

\section{Socio-Legal Rights of Citizens in the Neo-liberal Era}

The idea of Neo-liberalism denotes a pattern of repeated claims made by advocates, policy makers and scholars in the ongoing contest amongst the imperatives of market economics and non-market values beached in the necessities of democratic legitimacy. It has also been associated with a kind 
of ideological expansionism Neoliberalism like- classical liberalism in which market-modeled concepts of efficiency and autonomy shape policy, doctrine, and other discourses of legitimacy. Neoliberal claims spread the market side of this contest in capitalist democracies and this contest is persistent due to demands that capitalist markets make on the legal and political order for familiar protections of property and contract and also for a favorable return on investment and for managerial authority. The citizens in democratic country incline to embrace a fixed of expectations about political and economic life that may go beyond or contradict market logic as for example, economic opportunity, fairness in all aspect, safety in workplace, community and solidarity and civic equality, etc. When surged in politics then these expectations turn into candidates for criteria of democratic legitimacy so that's why democracy makes its own demands in which can prove incompatible with these imperatives and hostile to the conception of personhood and politics that they entail. Neoliberalism form the sense from this contest amid market imperatives and democratic demands (Grewal, David Singh and Purdy, Jedediah 2014). ${ }^{8}$

However, majority of people believed in last years that economic and social inequalities were unfair and because of this the transformation accordingly which power and domination have come to be supposed that this is no longer the case. As a result, the freedoms for which individual desires have paradoxically come to be pursued within the limits of neoliberalism. The ideology which supports "the expansion of competitive markets into all areas of life plus the economy, politics and society." This has altered the conventional dynamic between the desire for security and the aspiration for freedom, the comfort of community and the rights of the individual in this changing world, the fraternity necessary for social solidarity is being experienced as cultural majoritarianism. Yet neoliberalism reduces citizens to mere consumers, it deploys the language of liberty and choice, giving individuals the opportunity to aspire to dignity and mobility by connecting them to the modern market although the appeal of neoliberalism cannot be underestimated. Even the notion of citizenship is excavated by neoliberalism, the cultural majoritarianism operating together with claims to foster a sense of community (Gudavarthy, Ajay. September 3, 2019). ${ }^{9}$

The Constitution of India, 1950 intended to be a transformative document and was imparted with an assurance of three over-arching themes as- "protecting and enhancing national unity and integrity; establishing the institutions and spirit of democracy; fostering a social revolution to 
better the lot of the people of India." The elected representatives of the people would take the lead in relation to socio-economic transformation, thus the Indian Constitution contains mainly guarantees of civil and political rights ${ }^{10}$, along with Directive Principles of State Policy (DPSP) ${ }^{11}$ proposed for the guidance of the elected branches of government. Nevertheless, the courts in India and the Supreme Court embarked in the mid-1970s on a series of unprecedented and electrifying initiatives which cumulatively have come to be known as the court's Public Interest Litigation (PIL) jurisdiction. The purpose of this new initiative was to strengthen and the protection of the socio-economic rights of India's poor and also the PIL, embraced an expansive understanding of the content of the Article $21^{12}$ of the Constitution of India encompass rights to "the bare necessaries of life such as adequate nutrition, clothing and shelter and facilities for reading, writing and expressing one-self in diverse forms" (O'Connell, Paul. 2011). ${ }^{13}$

The Constitution visualizes the formation of a welfare State at the Central as well as at the State level. The primary duty of the Government in a welfare State is to secure the welfare of the people, providing adequate medical facilities for the people is an essential part of the obligation undertaken by the Government. The Government fulfil this commitment by running hospitals and health centers which provide medical care to the person seeking to avail of those facilities. Preservation of human life is thus of paramount importance and Article 21 imposes an obligation on the State to safeguard the right to life of every person. The Government hospitals run by the State and the clinics are under duty bound to extend medical assistance for preserving human life. In case failure on the part of a Government hospital to provide timely medical treatment to a person in need of such treatment considered as a results in a violation of his right to life guaranteed under Article 21 as given in the case of Paschim Banga Khet Mazdoor v. State of West Bengal. ${ }^{14}$

\section{Major Political Issues Confronting India Today: Debate, Discontent and Dilemma}

India has a 70-year tradition of democracy, equality and the rule of law, as well as a track record of effectively handling its diverse cultural and religious communities. The Citizenship Amendment Act (CAA) was passed on December 11, 2019, by the Indian government, amending the Citizenship Act of 1955. This new law has sparked protests and tensions across India, as it is feared that citizenship would be decided based on religious requirements, weakening the country's traditional secularism, according to both internal and external observers. The government's 
decision to create a national registry of people has heightened Muslim fears of discrimination. At the same time, India's economy is in a serious downturn as even before the coronavirus outbreak, the country's growth was slowing, as was job creation, though unemployment is strong, consumer confidence and spending are poor, and faith in the banking sector is eroding due to credit vulnerability and non-performing loans.

\section{Concluding Observations}

The NRC mandate, which is contained in Section 14 of the Citizenship Act of 1955, was inserted by way of Amendment Act, 2003, w.e.f. 3.12.2004, during the Congress administration, and there have been no challenges to this requirement since then. The CAA 2019 has nothing to do with the NRC; rather, it protects certain groups of people from being classified as illegal migrants and intends to grant them citizenship if they meet certain criteria outlined in the Citizenship Act. The constitutional objections to CAA 2019 are likely to be based on Articles 14, 15, 16, and 21 of the Constitution. It is necessary to note that this amendment cannot be challenged on the grounds of Articles 15 and 16, since the immunity offered by those articles extends only to Indian citizens, not to other people living in India, whether they are illegal migrants or not. Article 21 states unequivocally that no one's life or personal liberty may be taken away without due process of law. As a result, the CAA cannot be challenged under Article 21. In contrast, Article 14 guarantees equality before the law and equal protection under the law to all citizens and non-citizens in India, so CAA can only be challenged under this provision. However, there are numerous Supreme Court decisions stating that the concept of equality enshrined in Article 14 applies only to equals and not to unequals. As a result, while Article 14 prohibits discrimination, it does not prohibit classification based on discernible differences with a reasonable connection to the Act's object. CAA's classification is reasonable and based on discernible differences. It exempts a group of Pakistanis, Afghans, and Bangladeshis who were religiously persecuted in their home countries and sought refuge in India before December 31, 2014. They have origins in undivided India, and they or their ancestors were people of undivided India before the partition, fighting the freedom struggle alongside other Indians. Unfortunately, at the time of partition, they chose one of these three nations and as a result, they have faced unending persecution in the name of faith in these countries. They had been killed in large numbers in recent years, resulting in a dramatic reduction in their 
population in these countries, and they are now facing genocide, so they sought refuge in India to save their lives and families. In these nations, they don't even have access to basic human rights. Muslims in these countries are not included in this grouping. In these nations, Muslims have never been persecuted for their faith. They are citizens of these nations, and the vast majority of them enjoy all of the rights to a dignified life that the CAA protected class does not. They arrive in India with the aim of spreading terrorism rather than seeking refuge. As a result, they cannot be treated on an equal basis with the protected group.

The hue and cry raised by protestors by falsely inciting people to believe that every Muslim citizen of India's citizenship will be snatched, arrested, or thrown out of India under the CAA or NRC is totally unfounded. The National Registration Commission (NRC) would be merely a procedural element of the mandate given under section 14A of the Citizenship Act, which took effect on December 3, 2004, and in compliance with the Rules of 2003. A individual can prove his birth in India by any document such as a birth certificate, school certificate, PAN card, passport, voter I card, Aadhar, bank account, driving licence, and so on, including affidavits or certificates by village Panchayats or municipalities, according to the cumulative conjecture of all prevailing laws and procedures in this regard. Even if his nationality is found doubtful for not having any of these documents, the question will be decided by Sub District Registrar after giving him opportunity of being heard and in case of adverse order, such person shall have a right of appeal before District Registrar and against whose order he can file writ petition before High Court under Article 226 of the Constitution and lastly he can approach the Hon'ble Supreme Court under Article 136 of the Constitution. Also, there is a parallel process in place for illegal migrants to refer their cases to a designated Foreigners Tribunal for judicial review, after which a writ petition can be filed in the High Court and then an SLP in the Hon'ble Supreme Court. As a result, provocation based solely on fear of what will be the conditions for proving citizenship in the future NRC is extremely premature. The citizenship requirements are already set out in our Constitution and the Citizenship Act. NRC, as a procedural feature of the requirements set forth in the Constitution and Citizenship Act, cannot supersede the Constitution or Citizenship Act, nor can it enforce criteria that are not set forth in either. It will be a list of Indian citizens who meet the citizenship standards outlined in the Constitution or the Citizenship Act. Thus, CAA nowhere prescribes any condition that it will snatch citizenship of any person who are already citizens of India by any manner prescribed in 
Constitution or Citizenship Act. The Central Government is required to include a detailed list of documents that would be admissible proof of citizenship for different groups of people at the time of issuance of the NRC notification, which is absent from the Citizenship (Registration of Citizens and Issue of National Identity Cards) Rules 2003. However, some groups are attempting to profit by spreading rumours that they will be discriminated against, that their citizenship will be taken away, or that they will be thrown out of the country. The government should ensure that the NRC, which is an important register for welfare schemes and the smooth running of the country, is not used by shady characters to spread rumours or threaten the country's peace and harmony.

\section{References}

${ }^{1}$ Small, N. (1977). Citizenship, Imperialism and Independence: British Colonial Ideals and Independent African States (1st part) / CITOYENNETE, IMPERIALISME ET INDEPENDANCE: IDEAUX DU COLONIALISME BRITANNIQUE ET PAYS INDEPENDANTS D'AFRIQUE. Civilisations, 27(1/2), 17-43. Retrieved March 18, 2021, from http://www.jstor.org/stable/41803084.

${ }^{2}$ Amendment on December 3, 2004.

${ }^{3}$ Ghosh, Atasi (September 13, 2018). What We Talk About When We Talk About Citizenship in India. Retrieved from: https://thewire.in/law/what-we-talk-about-when-we-talk-about-citizenshipin-india (Accessed 15 March 2021).

${ }^{4}$ UN (n.d). Refugees and Migrants. Retrieved from: https://refugeesmigrants.un.org/definitions (Accessed 10 March 2021).

${ }^{5} \mathrm{UN}$ (n.d). Refugees and Migrants. Retrieved from: https://refugeesmigrants.un.org/definitions (Accessed 10 March 2021).

${ }^{6}$ Refugee Convention, 1951 and Protocols, 1967.

${ }^{7}$ UNHCR (September 2011). The 1951 Conventioon relating to the Status of Refugees and its 1967 Protocol. Retrieved from: https://www.unhcr.org/4ec262df9.pdf (Accessed 14 March 2021).

${ }^{8}$ Grewal, David Singh and Purdy, Jedediah. (2014). Introduction: Law and Neoliberalism. Retrieved from: http://www.igntu.ac.in/eContent/IGNTU-eContent-340797065733-MAPoliticalScience-2-Dr.GeorgeT.Haokip-Paper202ContemporaryPoliticalTheory-Unit2.pdf (Accessed 15 March 2021)

${ }^{9}$ Gudavarthy, Ajay. (September 3, 2019) Neoliberalism is killing the very idea of citizenship in India. Retrieved from: https://qz.com/india/1700542/neoliberalism-is-killing-the-very-idea-ofcitizenship-in-india/ (Accessed 20 March 2021)

${ }^{10}$ Part III contains the Fundamental Rights (Article 12 to 35).

${ }^{11}$ Part IV contains the Directive Principles of State Policy (Article 36 to 51). 
${ }^{12}$ Article 21- The right to life and personal liberty.

13 O'Connell, Paul. (2011) The Death of Socio-Economic Rights. Retrieved from: https://warwick.ac.uk/fac/arts/history/ecc/events/writingrights/workshopprogramme/readingmate rials/oconnell2-death_of_socio-economic_rights.pdf (Accessed 20 March 2021)

${ }^{14}$ (1996) 4 SCC 37. 